\title{
ANALISIS DETERMINAN PEMANFAATAN EDMODO DENGAN MENGGUNAKAN UNIFIED THEORY OF ACCEPTANCE AND USE OF TECHNOLOGY (UTAUT)
}

\section{DETERMINAN ANALYSIS OF USING EDMODO USING UNIFIED THEORY OF ACCEPTANCE AND USE OF TECHNOLOGY (UTAUT)}

\author{
Oleh: \\ Ervie Sabrina Nuari \\ Ahmad Nurkhin \\ Kardoyo \\ Fakultas Ekonomi Universitas Negeri Semarang \\ ahmadnurkhin@mail.unnes.ac.id
}

\begin{abstract}
Abstrak
Penelitian ini bertujuan untuk menganalisis faktor-faktor yang mempengaruhi pemanfaatan Edmodo dengan menggunakan model Unified Theory of Acceptance and Use of Technology (UTAUT). Populasi dalam penelitian ini adalah peserta didik kelas XII SMK Negeri 2 Semarang program keahlian akuntansi, administrasi perkantoran, dan pemasaran sebanyak 319 orang. Sampel penelitian sebanyak 178 siswa. Teknik pengambilan sampel menggunakan proportionate random sampling. Teknik pengumpulan data dilakukan dengan menggunakan kuesioner yang dikembangkan dari model UTAUT. Teknik analisis data yang digunakan adalah analisis deskriptif dan analisis jalur dengan bantuan software program IBM SPSS 21.0. Hasil penelitian menunjukkan performance expectancy dan facilitating condition memiliki pengaruh langsung dan tidak langsung terhadap use behavior melalui behavioral intention. Hasil lainnya menunjukkan bahwa social influence tidak berpengaruh secara langsung terhadap use behavior dan behavioral intention tetapi memiliki pengaruh tidak langsung terhadap use behavior melalui behavioral intention. Effort expectancy tidak memiliki pengaruh langsung terhadap behavioral intention dan tidak memiliki pengaruh tidak langsung terhadap use behavior melalui behavioral intention. Namun demikian effort expectancy terbukti memiliki pengaruh langsung terhadap use behavior. Terakhir, behavioral intention terbukti berpengaruh signifikan terhadap use behavior.
\end{abstract}

Kata Kunci: Edmodo, UTAUT, use behavior, behavioral intention

\section{Abstract}

This study aims to analyze the factors that influence the utilization of Edmodo by using the Unified Theory of Acceptance and Use of Technology (UTAUT) model. The population in this study were students of class XII of SMK Negeri 2 Semarang, accounting, office administration, and marketing department as many as 319 students. The research sample was 178 students. The sampling technique used was proportionate random sampling. Data collection techniques were carried out using a questionnaire developed from the UTAUT model. The data analysis technique used is descriptive analysis and path analysis by using IBM SPSS 21.0 software program. The results of the study show that performance expectancy and facilitating conditions have a direct and indirect influence on use behavior through behavioral intention. Other results show that social influence does not directly influence the use of behavior and behavioral intention but has an indirect influence on use behavior through behavioral intention. Effort expectancy does not have a direct influence on behavioral intention and does not have an indirect influence on use behavior through behavioral intention. However, effort expectancy has proven to have a direct influence on use behavior. Finally, behavioral intention has a significant effect on use behavior. 
Key words: Edmodo, UTAUT, use behavior, behavioral intention

PENDAHULUAN

Perkembangan teknologi informasi yang semakin pesat, kebutuhan akan suatu konsep dan mekanisme belajar berbasis teknologi informasi menjadi tidak terelakan lagi. Munir (2010) berpendapat bahwa kemajuan teknologi informasi dan komunikasi (TIK) dalam bidang pendidikan membuka cakrawala baru bagi pembukaan kesempatan (akses) dan peningkatan mutu pendidikan di semua jenjang, jalur, dan jenis pendidikan. Tan (2013) menjelaskan bahwa perkembangan internet menimbulkan efisiensi waktu dan lokasi pembelajaran dan menarik peserta didik untuk menggunakan pemebelajaran secara online untuk mengejar pembelajaran yang mereka pilih.

$$
\text { Thomas \& Setiaji (2014) }
$$

menyatakan bahwa upaya untuk meningkatkan kualitas proses, hasil dan outcome dalam pembelajaran antara lain dengan mengembangkan strategi pembelajaran, media pembelajaran dan evaluasi pembelajaran. Pengembangan strategi dan media pembelajaran dimaksudkan untuk menemukan metode yang tepat yang dapat diimplementasikan oleh pengajar dalam rangka upaya untuk meningkatkan kualitas dan hasil pembelajaran. Hal yang kurang lebih sama juga diungkapkan oleh Herayanti, Fuadunnazmi, \& Habibi (2017). Asrori \& Fachrurrozie (2011) menjelaskan bahwa seiring dengan kemajuan teknologi sistem informasi dan tuntutan globalisasi modelmodel pembelajaran cyber learning atau electronic learning (e-learning) diprediksikan akan mendominasi pelaksanaan pembelajaran dimasa mendatang. Mumpuni \& Nurpratiwiningsih (2018) mengembangkan pembelajaran berbasis web untuk meningkatkan kemampuan menulis kreatif mahasiswa.

Institusi pendidikan (sekolah, perguruan tinggi) telah menggunakan internet dan e-learning untuk meningkatkan kualitas pembelajaran. Kecenderungan dalam menggunakan e-learning sebagai salah satu alternatif kegiatan belajar di berbagai lembaga pendidikan semakin meningkat sejalan dengan adanya perkembangan teknologi informasi dan komunikasi. Divayana (2017) berpendapat bahwa e-learning mudah dan cepat digunakan untuk dapat membantu proses pembelajaran baik di kelas maupun di luar kelas. Mckeown \& Anderson (2016) mengemukakan bahwa pendidik menyampaikan materi melalui platform pembelajaran online memerlukan pendekatan yang lebih bernuansa daripada "ukuran satu cocok untuk semua" yang cenderung diadopsi.

Salah satu bentuk pembelajaran online berbasis internet adalah Edmodo. Banyak sekolah yang telah memanfaatkan aplikasi pembelajaran online ini. menurut SEAMLOC dalam Dharmawati (2017) Edmodo merupakan suatu layanan gratis yang memungkinkan dosen dapat menciptakan dan memelihara komunitas kelas mereka sendiri dengan aman. Menurut SEAMLOC edmodo adalah platform media sosial yang sering digambarkan sebagai facebook untuk sekolah dan dapat berfungsi lebih banyak lagi sesuai dengan kebutuhan. Edmodo dikembangkan berdasarkan prinsip-prinsip pengelolaan kelas berbasis kelompok dan juga sosial media. Edmodo sangat komprehensif sebagai sebuah course management system seperti Moodle, bedanya adalah aksesnya lebih cepat dan lebih mudah menggunakannya dengan menggunakan beberapa fitur yang fungsinya sama seperti course management system.

SMK Negeri 2 Semarang telah menggunakan platform Edmodo untuk menunjang pembelajaran. Namun demikian, penggunaan Edmodo belum maksimal. Guru belum menggunakan Edmodo dengan baik karena belum merasakan manfaatnya. Siswa mengalami 
kendala dalam menggunakan Edmodo. Perilaku pengguna yang kurang maksimal tersebut dapat disebabkan oleh beberapa faktor. Model UTAUT (Unified Theory of Acceptance and Use of Technology) dapat digunakan untuk memahami dan menganalisis determinan penggunaan teknologi informasi. Model UTAUT dikembangkan oleh Venkatesh, Morris, Davis, \& Davis (2003) melalui pengkajian yang dilakukan terhadap delapan model/teori penerimaan/adopsi teknologi yang banyak digunakan dalam penelitian sistem informasi sebelumnya.

Model UTAUT telah digunakan oleh beberapa peneliti. Namun, hasil yang diperoleh masih beragam. Sari (2011) menemukan kontruk performance expectancy tidak berpengaruh terhadap use behavior, namun kontruk-kotruk lainnya seperti effort expectancy, social influence, facilitating condition, dan behavioral intention berpengaruh terhadap use behavior. Rivai (2014) dalam hasil penelitiannya menunjukkan bahwa performance expectancy, effort expectancy, social influence dan facilitating conditions berpengaruh positif terhadap behavior intention to use the system. Sikumbang (2014) dan Kurniabudi \& Assegaff (2016) menemukan bahwa kontruks effort expectancy dan social influence tidak berpengaruh positif signifikan behavioral intention, namun kontruk-kontruk lainnya seperti performance expectation, facilitating condition berpengaruh teradap behavioral intention.

Muhsin, Thomas, \& Nurkhin
(2016) hanya berhasil membuktikan
pengaruh positif dan signifikan
performance expectancy dan social
influence terhadap behavioral intention.
Sementara effort expectancy tidak terbukti
mempunyai pengaruh terhadap intention to
use e-journal. Hartati (2017) membuktikan
bahwa performace expectancy dan effort
expectancy memiliki hubungan pengaruh
positif artinya penerapan aplikasi e-

learning. Tarhini, Masa'deh, Al-Busaidi, Mohammed, \& Maqableh (2017) menemukan bahwa behavioral intention secara signifikan dipengaruhi oleh performance expectancy, effort expectancy, dan social influence. Sedangkan facilitating condition tidak terbukti berpengaruh terhadap adopsi $e$ learning oleh siswa.

UTAUT juga diterapkan dalam kerangka bisnis. Agustina (2013) menemukan tidak ada pengaruh positif dan signifikan pada kontruk social influence terhadap use behavior, namun kontrukkontruk lainnya seperti performance expectation, effort expectation, facilitating conditions dan behavioral intention memiliki pengaruh yang positif signifikan terhadap use behavior. Sancaka \& Subagio (2014) menemukan pengaruh positif dan signifikan performance expectancy dan effort expectancy terhadap behavioral intention pengunaan kompas epaper. Tarhini, El-Masri, Ali, \& Serrano (2016) menemukan performance expectancy dan social influence terbukti berpengaruh positif dan signifikan terhadap behavioral intention to use internet banking. Sedangkan effort expectancy tidak terbukti mempunyai pengaruh yang signifikan.

$$
\text { Penelitian ini kembali }
$$

menggunakan model UTAUT untuk menganalisis determinan pemanfaatan Edmodo di SMK Negeri 2 Semarang. UTAUT yang digunakan adalah model original. Venkatesh (2012) mengembangkan model original UTAUT menjadi UTAUT2 dengan menambahkan konstruk hedonic motivation, price value, dan habit. (Chang, 2012) juga berpendapat bahwa UTAUT2 bisa lebih mengeksplorasi temuan mengenai faktor yang mempengaruhi penerimaan dan pemanfaatan sistem. Namun demikian, UTAUT2 kurang relevan jika diterapkan dalam penelitian ini. UTAUT2 lebih tepat digunakan dalam kerangka perilaku konsumsi online. Di samping itu, penelitian ini mempunyai perbedaan pada 
analisis data yang berusaha untuk menguji peran mediasi dari behavioral intention. Beberapa peneliti hanya melakukan pengujian pengaruh langsung dari konstruk UTAUT.

\section{METODE PENELITIAN}

Penelitian yang dilakukan adalah penelitian kuanitatif. Desain penelitian yang digunakan dalam penelitian ini adalah studi pengujian hipotesis (hypothesis study), yaitu menguji dengan menganalisis, mendeskripsikan dan mendapatkan bukti empiris hubungan antara dua variabel atau lebih.

\section{Populasi dan Sampel Penelitian}

Populasi dalam penelitian ini adalah peserta didik SMK Negeri 2 Semarang tahun ajaran 2018/2019 yang berjumlah 319 orang. Terdiri dari 117 siswa program keahlian akuntansi, 118 siswa program keahlian administrasi perkantoran, dan 114 siswa program keahlian pemasaran. Sampel penelitian adalah sebanyak 178 siswa yang dihitung dengan rumus Slovin pada tingkat kesalahan 5\%. Metode pengambilan sampel adalah proportionate random sampling. Dengan demikian, komposisi sampel penelitian adalah 60 siswa program keahlian akuntansi, 60 siswa program keahlian administrasi perkantoran, dan 58 siswa program keahlian pemasaran.

\section{Definisi Operasional Variabel}

Penelitian ini menggunakan model UAUT yang sudah diadaptasi sesuai dengan tujuan penelitian. Variabel penelitian ini terdiri dari tiga variabel, yaitu variabel terikat (use behavior atau perilaku pengguna), variale bebas (performance expectancy, effort expectancy, social influence dan facilitating conditions), dan variabel mediasi (behavioral intention). Definisi operasional variabel tampak pada tabel berikut ini.

Tabel 1. Definisi Operasional Variabel Penelitian

\begin{tabular}{|l|l|l|l|}
\hline No. & \multicolumn{1}{|c|}{ Variabel } & \multicolumn{1}{c|}{ Definisi Operasional } & \multicolumn{1}{c|}{ Indikator Pengukuran } \\
\hline 1. & use behavior & $\begin{array}{l}\text { perilaku siswa yang } \\
\text { didefinisikan sebagai } \\
\text { intensitas dan atau } \\
\text { frekuensi pemakai dalam } \\
\text { menggunakan Edmodo }\end{array}$ & intensity of use \\
\hline 2. & behavioral intention & $\begin{array}{l}\text { ukuran kekuatan niat } \\
\text { peserta didik untuk } \\
\text { melakukan penggunaan } \\
\text { Edmodo }\end{array}$ & attitude toward behavior \\
\hline 3. & $\begin{array}{l}\text { performance } \\
\text { expectancy }\end{array}$ & $\begin{array}{l}\text { tingkat di mana peserta } \\
\text { didik percaya bahwa } \\
\text { menggunakan Edmodo } \\
\text { akan membantu dirinya } \\
\text { untuk memperoleh manfaat } \\
\text { dalam melakukan kegiatan } \\
\text { belajar }\end{array}$ & $\begin{array}{l}\text { perceived usefulness } \\
\text { (perspektif penggunaan) } \\
\text { extrinsic motivation (motivasi } \\
\text { ekstrinsik) } \\
\text { job-fit } \text { (kesesuaian tugas) } \\
\text { relative advantage } \\
\text { (keuntungan relatif) } \\
\text { outcome expectation (harapan } \\
\text { hasil) }\end{array}$ \\
\hline 4. & effort expectancy & $\begin{array}{l}\text { tingkat kemudahan yang } \\
\text { didapat oleh peserta didik } \\
\text { terkait penggunaan } \\
\text { Edmodo dalam kegiatan } \\
\text { belajar di sekolah ataupun }\end{array}$ & $\begin{array}{l}\text { perceived ease of use } \\
\text { (perspektif kemudahan } \\
\text { penggunaan) } \\
\text { complexity ease of use }\end{array}$ \\
\hline
\end{tabular}


Jurnal Pendidikan Akuntansi Indonesia, Vol. XVII, No. 1, Tahun 2019

Ervie Sabrina Nuari, Ahmad Nurkhin \& Kardoyo

$57-73$

\begin{tabular}{|c|c|c|c|}
\hline & & $\begin{array}{l}\text { di perusahaan ketika } \\
\text { melaksanakan prakerin }\end{array}$ & $\begin{array}{l}\text { (kemudahan penggunaan } \\
\text { kompleks) }\end{array}$ \\
\hline 5. & social influence & $\begin{array}{l}\text { sejauh mana peserta didik } \\
\text { mempersepsikan bahwa } \\
\text { orang-orang penting } \\
\text { percaya bahwa teknologi } \\
\text { digunakan untuk menjadi } \\
\text { penting dan juga } \\
\text { bermanfaat dalam kegiatan } \\
\text { belajar }\end{array}$ & 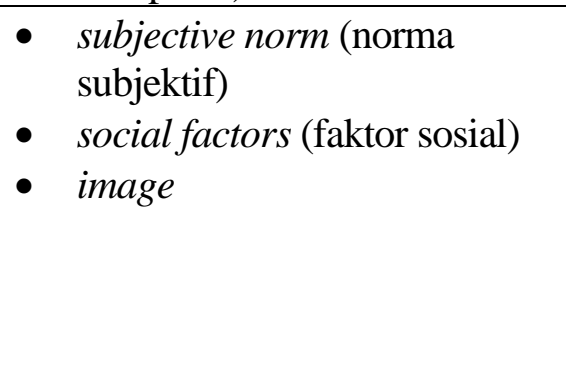 \\
\hline 6. & facilitating conditions & $\begin{array}{l}\text { tingkat di mana peserta } \\
\text { didik percaya bahwa } \\
\text { infrastruktur organisasi dan } \\
\text { teknis ada untuk } \\
\text { mendukung penggunaan } \\
\text { sistem dalam kegiatan } \\
\text { belajar di sekolah maupun } \\
\text { di perusahaan ketika } \\
\text { melaksanakan prakerin }\end{array}$ & $\begin{array}{l}\text { - } \begin{array}{l}\text { perceived behavioral control } \\
\text { (pengendalian presepsi }\end{array} \\
\text { perilaku) } \\
\text { - facilitating conditions (kondisi } \\
\text { yang memfasilitasi) } \\
\text { - compatability }\end{array}$ \\
\hline
\end{tabular}

Teknik Pengumpulan dan Analisis Data

Teknik pengumpulan data yang digunakan peneliti dalam penelitian ini menggunakan kuesioner/angket. Kuesioner dikembangkan dari konsep UTAUT dan instrumen yang telah digunakan penelitian sebelumnya. Peneliti menggunakan skala likert dengan 5 (lima) alternatif pilihan jawaban untuk pengukuran variabel penelitian.

Teknik analisis data yang digunakan adalah analisis statistik deskriptif dan analisis jalur (path analysis). Analisis deskriptif digunakan untuk penyajian deskripsi variabel penelitian. Analisis jalur digunakan untuk menguji hipotesis penelitian yang berusaha untuk menemukan determinan pemanfaatan Edmodo dengan menggunakan konsep UTAUT. Peneliti menggunakan alat bantu IBM SPSS 21.0 untuk mengolah data penelitian.

Analisis jalur yang telah dilakukan berdasarkan analisis dua persamaan regresi berikut ini;

Intention $=$ performance + effort + social_influence + facilitating_condition Use_behavior $=$ performance + effort + social_influence + facilitating_condition + intention

\section{HASIL PENELITIAN DAN PEMBAHASAN \\ Hasil Deskripsi Variabel Penelitian}

Tabel 2 menunjukkan statistik deskriptif variabel penelitian. Rata-rata variabel use behavior menunjukkan nilai sebesar 9,15 yang menunjukkan bahwa ratarata tingkat perilaku pengguna (use behavior) peserta didik kelas XII SMK Negeri 2 Semarang tahun 2018/2019 dalam menggunakan Edmodo dalam kategori sedang. Rata-rata variabel performance expectancy adalah sebesar 53,13 yang menunjukkan bahwa rata-rata tingkat performance expectancy (harapan kinerja) peserta didik kelas XII SMK Negeri 2 Semarang tahun 2018/2019 dalam menggunakan Edmodo dalam kategori tinggi.

Rata-rata variabel effort expectancy menunjukkan nilai sebesar 23,48 yang menunjukkan bahwa rata-rata tingkat effort expectancy (harapan usaha) peserta didik kelas XII SMK Negeri 2 Semarang tahun 2018/2019 dalam menggunakan Edmodo dalam kategori sedang.

Rata-rata variabel social influence menunjukkan nilai sebesar 24,43 yang menunjukkan bahwa rata-rata tingkat social influence (pengaruh sosial) peserta didik 
kelasXII SMK Negeri 2 Semarang tahun 2018/2019 dalam menggunakan Edmodo dalam kategori tinggi. Rata-rata nilai variabel facilitating conditions adalah sebesar 22,47 yang menunjukkan bahwa rata-rata tingkat facilitating conditions (kondisi yang memfasilitasi) peserta didik kelas XII SMK Negeri 2 Semarang tahun 2018/2019 dalam menggunakan Edmodo dalam kategori tinggi. Rata-rata nilai variabel behavioral intention adalah sebesar 10,23 yang menunjukkan bahwa rata-rata tingkat perilaku pengguna (use behavior) peserta didik kelas XII SMK Negeri 2 Semarang tahun ajaran 2018/2019 dalam menggunakan Edmodo dalam kategori sedang.

Tabel 2. Statistik Deskriptif Variabel Penelitian

\begin{tabular}{|l|l|c|c|c|c|}
\hline No. & \multicolumn{1}{|c|}{ Variabel } & Minimum & Maximum & Mean & Std. Deviation \\
\hline 1. & use behavior & 3 & 13 & 9,15 & 2,266 \\
\hline 2. & behavioral intention & 3 & 15 & 10,23 & 2,316 \\
\hline 3. & performance expectancy & 31 & 70 & 53,13 & 7,735 \\
\hline 4. & effort expectancy & 13 & 51 & 23,48 & 4,154 \\
\hline 5. & social influence & 14 & 58 & 24,43 & 3,984 \\
\hline 6. & facilitating conditions & 11 & 30 & 22,47 & 3,254 \\
\hline
\end{tabular}

\section{Hasil Uji Prasyarat dan Asumsi Klasik}

Hasil uji normalitas menggunakan uji

Kolmogorov-smirnov menunjukkan besarnya nilai kolmogrof-smirnov dengan use behavior sebagai variabel dependen adalah 0,927 dengan signifikansi sebesar 0,357>0,05. Dengan demikian dapat diartikan bahwa data yang diperoleh dari variabel use behavior berdistribusi normal sehingga analisis data dapat dilanjutkan. Sedangkan nilai kolmogrofsmirnov dengan behavioral intention sebagai variabel dependen adalah 1,105 dengan signifikansi sebesar $0,174>0,05$. Sehingga dapat diartikan bahwa data yang diperoleh dari variabel behavioral intention berdistribusi normal sehingga analisis data dapat dilanjutkan.

Hasil uji multikolonieritas dengan variabel use behavior sebagai variabel dependen menunujukan bahwa nilai tolerance untuk variabel performance expectancy (PE) sebesar 0,489 dan nilai VIF sebesar 2,047; nilai tolerance variabel effort expectancy (EE) sebesar 0,659 dan nilai VIF sebesar 1,518; nilai tolerance variabel social influence (SI) sebesar 0,773 dan nilai VIF sebesar 1,293; nilai tolerance facilitating conditions (FC) sebesar 0,654 dan nilai VIF sebesar 1,528; nilai tolerance behavioral intention (BI) sebesar 0,622 dan nilai VIF sebesar 1,608. Hasil tersebut dapat dilihat bahwa nilai tolerance dari keempat variabel bebas dan satu variabel intervening lebih dari 0,10 dan nilai VIF kurang dari 10 sehingga dapat disimpulkan bahwa dalam regresi penelitian ini tidak terjadi multikolonieritas sehingga analisis data dapat dilanjutkan.

Hasil uji multikolonieritas dengan variabel behavioral intention sebagai variabel dependen menunujukan bahwa nilai tolerance untuk variabel performance expectancy (PE) sebesar 0,567 dan nilai VIF sebesar 1,765; nilai tolerance variabel effort expectancy (EE) sebesar 0,665 dan nilai VIF sebesar 1,503; nilai tolerance variabel social influence (SI) sebesar 0,782 dan nilai VIF sebesar 1,278; nilai tolerance facilitating conditions (FC) sebesar 0,716 dan nilai VIF sebesar 1,397. Hasil tersebut dapat dilihat bahwa nilai tolerance dari keempat variabel bebas lebih dari 0,10 dan nilai VIF kurang dari 10 sehingga dapat disimpulkan bahwa dalam regresi penelitian ini tidak terjadi multikolonieritas sehingga analisis data dapat dilanjutkan

Hasil uji heteroskedastisitas dengan menggunakan uji glejser menunjukkan bahwa nilai signifikansi variabel performance expectancy (PE) sebesar 0,074; effort expectancy (EE) sebesar 0,133; social influence (SI) sebesar 0,389; facilitating conditions (FC) sebesar 0,961 dan behavioral 
intention (BI) sebesar 0,081 . Nilai signifikansi dari kelima variabel lebih dari 0,05 sehingga dapat disimpulkan bahwa model regresi dengan use behavior sebagai variabel dependen dalam penelitian ini tidak mengandung heteroskedastisitas sehingga model regresi dinyatakan layak digunakan dalam memprediksi perilaku penggunaan Edmodo.

Hasil uji glejser dengan variabel behavioral intention sebagai variabel dependen menunjukkan bahwa nilai signifikansi variabel performance expectancy (PE) sebesar 0,235; effort expectancy (EE) sebesar 0,756; social influence (SI) sebesar
0,269; facilitating conditions (FC) sebesar 0,243 . Nilai signifikansi dari keempat variabel lebih dari 0,05 maka dapat disimpulkan bahwa model regresi dengan behavioral intention sebagai variabel dependen dalam penelitian ini tidak mengandung heteroskedastisitas sehingga model regresi dinyatakan layak digunakan dalam memprediksi niat menggunakan Edmodo.

\section{Hasil Analisis Jalur}

Analisis jalur dilakukan dengan menguji dua persamaan regresi yang telah dibentuk sebelumnya. Hasil analisis jalur dapat dilihat pada gambar berikut ini.

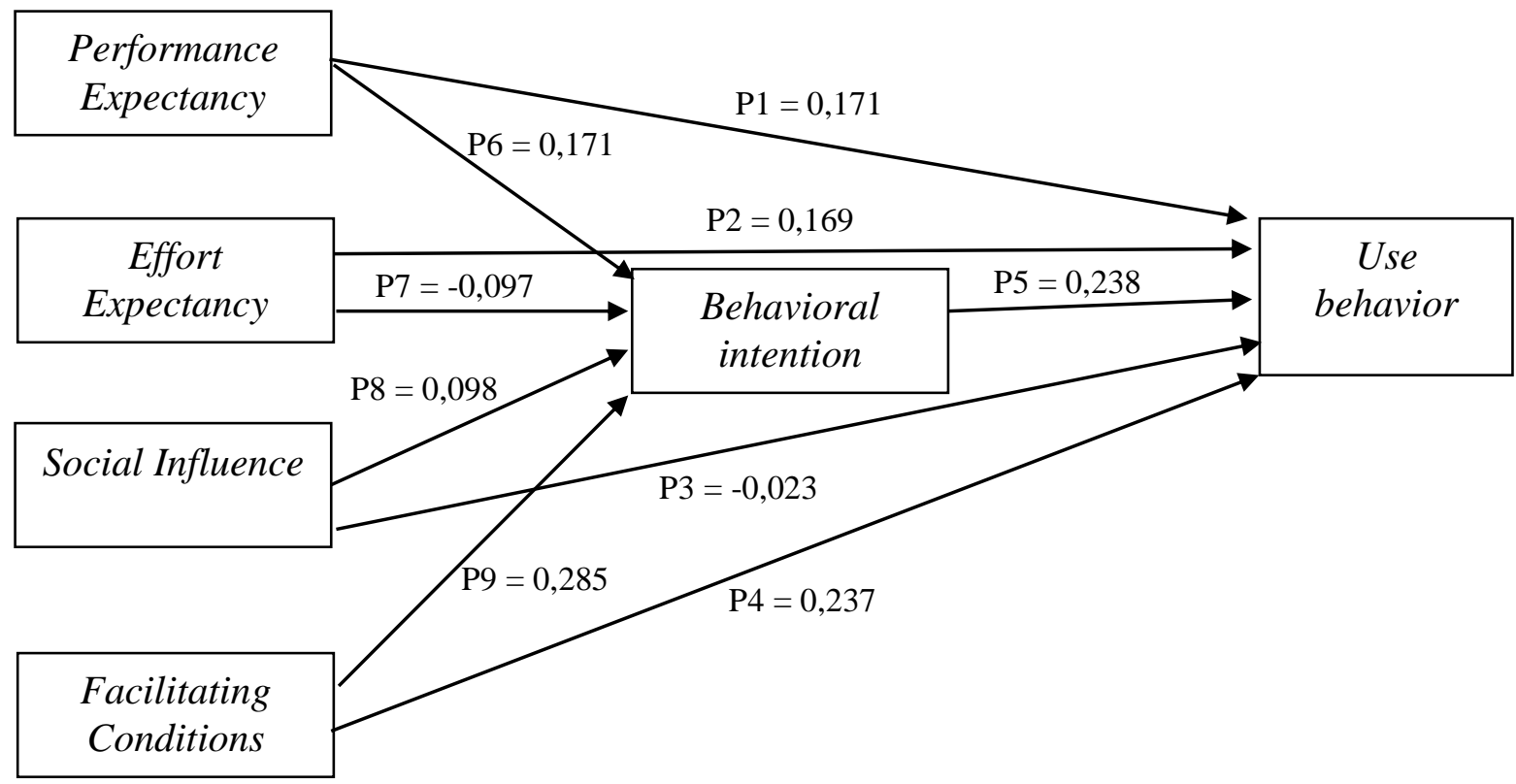

Gambar 1. Diagram Analisis Jalur Penelitian

Hasil Pengujian Hipotesis

Hasil uji hipotesis yang telah dilakukan dalam penelitian ini diangkum pada tabel berikut ini.

Tabel 3. Rangkuman Hasil Pengujian Hipotesis Penelitian

\begin{tabular}{|l|c|c|c|c|c|c|}
\hline \multirow{2}{*}{ Hipotesis Penelitian } & \multicolumn{2}{|c|}{ Koefisien Jalur } & Sig. & $\begin{array}{c}\mathbf{t} \\
\text { hitung }\end{array}$ & t tabel & $\begin{array}{c}\text { Keputusan } \\
\text { Hasil } \\
\text { Pengujian }\end{array}$ \\
\cline { 2 - 6 } & $\mathbf{L}$ & $\mathbf{T L}$ & Sda pengaruh signifikan \\
$\begin{array}{l}\text { positif performance } \\
\text { expectancy terhadap use } \\
\text { behavior }\end{array}$ & 0,171 & & 0,048 & & & Diterima \\
\hline $\begin{array}{l}\text { Ada pengaruh signifikan } \\
\text { positif effort expectancy } \\
\text { terhadap use behavior }\end{array}$ & 0,169 & & 0,023 & & & Diterima \\
\hline
\end{tabular}


Jurnal Pendidikan Akuntansi Indonesia, Vol. XVII, No. 1, Tahun 2019

Ervie Sabrina Nuari, Ahmad Nurkhin \& Kardoyo

$57-73$

\begin{tabular}{|c|c|c|c|c|c|c|}
\hline $\begin{array}{l}\text { Ada pengaruh signifikan } \\
\text { positif social influence } \\
\text { terhadap use behavior. }\end{array}$ & $-0,023$ & & 0,740 & & & Ditolak \\
\hline $\begin{array}{l}\text { Ada pengaruh signifikan } \\
\text { positif facilitating condition } \\
\text { terhadap use behavior. }\end{array}$ & 0,237 & & 0,002 & & & Diterima \\
\hline $\begin{array}{l}\text { Ada pengaruh signifikan } \\
\text { positif behavioral intention } \\
\text { terhadap use behavior. }\end{array}$ & 0,238 & & 0,002 & & & Diterima \\
\hline $\begin{array}{l}\text { Ada pengaruh signifikan } \\
\text { positif performance } \\
\text { expectancy terhadap } \\
\text { behavioral intention. }\end{array}$ & 0,419 & & 0,000 & & & Diterima \\
\hline $\begin{array}{l}\text { Ada pengaruh signifikan } \\
\text { positif effort expectancy } \\
\text { terhadap behavioral } \\
\text { intention. }\end{array}$ & $-0,097$ & & 0,189 & & & Ditolak \\
\hline $\begin{array}{l}\text { Ada pengaruh signifikan } \\
\text { positif social influence } \\
\text { terhadap behavioral } \\
\text { intention. }\end{array}$ & 0,098 & & 0,150 & & & Ditolak \\
\hline $\begin{array}{l}\text { Ada pengaruh signifikan } \\
\text { positif facilitating condition } \\
\text { terhadap behavioral } \\
\text { intention. }\end{array}$ & 0,285 & & 0,000 & & & Diterima \\
\hline $\begin{array}{l}\text { Ada pengaruh signifikan } \\
\text { positif performance } \\
\text { expectancy terhadap use } \\
\text { behavior melalui behavioral } \\
\text { intention. }\end{array}$ & & 0,009 & 0,000 & 3,1629 & 1,634 & Diterima \\
\hline $\begin{array}{l}\text { Ada pengaruh signifikan } \\
\text { positif effort expectancy } \\
\text { terhadap use behavior } \\
\text { melalui behavioral intention. }\end{array}$ & & $-0,023$ & 0,028 & $-1,9037$ & 1,6534 & Ditolak \\
\hline $\begin{array}{l}\text { Ada pengaruh signifikan } \\
\text { positif social influence } \\
\text { terhadap use behavior } \\
\text { melalui behavioral intention. }\end{array}$ & & 0,023 & 0,023 & 1,9801 & 1,6534 & Diterima \\
\hline $\begin{array}{l}\text { Ada pengaruh signifikan } \\
\text { positif facilitating condition } \\
\text { terhadap use behavior } \\
\text { melalui behavioral intention. }\end{array}$ & & 0,067 & 0,002 & 2,8018 & 1,6534 & Diterima \\
\hline
\end{tabular}

Pembahasan Pengaruh Performance expectancy terhadap Use behavior

Hipotesis pertama yang diajukan dalam penelitian ini menguji pengaruh performance expectancy terhadap use behavior Edmodo pada peserta didik kelas
XII SMK Negeri 2 Semarang. Hipotesis tersebut mengasumsikan bahwa semakin baik performance expectancy yang dimiliki oleh peserta didik maka perilaku pengguna (use behavior) E-learning System (Edmodo) juga akan meningkat. Hasil uji t pada Tabel 3. 
menunjukkan bahwa variabel performance expectancy memiliki nilai signifikansi $0,048<$ 0,05 dan koefisien regresi menunjukkan hasil yang positif. Artinya performance expectancy berpengaruh signifikan dan positif terhadap perilaku pengguna (use behavior) E-learning System (Edmodo) pada peseta didik kelas XII SMK Negeri 2 Semarang.

Hasil penelitian ini sesuai dengan teori model penerimaan teknologi (UTAUT) oleh Venkatesh et al. (2003), salah satu faktor yang mempengaruhi perilaku pengguna (use behavior) performance expectancy. Hasil penelitian juga sejalan dengan hasil penelitian yang diperoleh Sari \& P.S. (2013) dan Rivai (2014) yang menunjukkan adanya pengaruh positif performance expectancy terhadap use behavior. Hasil yang sama juga ditemukan oleh Sikumbang (2014) dan Prasetyo \& Anubhakti (2011).

Performance expectancy merupakan keyakinan seorang individu bahwa dengan dirinya menggunakan sistem dapat membantu mereka dalam menyelesaikan pekerjaan dan meningkatkan kinerjanya. Venkatesh et al. (2003) mendefinisikan performance expectancy sebagai tingkat dimana seorang individu meyakini bahwa dengan menggunakan sistem akan membantu dalam meningkatkan kinerjanya. Peserta didik kelas XII SMK Negeri 2 Semarang menunjukkan bahwa mereka memiliki performance expectancy yang kedepannya dapat membantu dan bermanfaat untuk dirinya. Menyadari adanya performance expectancy akan memudahkan peserta didik untuk berperilaku dalam penggunaan suatu sistem.

\section{Pembahasan Pengaruh Effort expectancy terhadap Use behavior}

Hipotesis kedua yang diajukan dalam penelitian ini menguji pengaruh effort expectancy terhadap use behavior Edmodo pada peserta didik kelas XII SMK Negeri 2 Semarang. Hipotesis tersebut mengasumsikan bahwa semakin baik effort expectancy yang dimiliki oleh peserta didik maka use behavior Edmodo juga akan meningkat. Hasil uji t pada Tabel 3 menunjukkan bahwa variabel effort expectancy memiliki nilai signifikansi $0,023<$ 0,05 dan koefisien regresi menunjukkan hasil yang positif. Hal ini berarti effort expectancy berpengaruh signifikan dan positif terhadap use behavior (Edmodo pada peseta didik kelas XII SMK Negeri 2 Semarang.

Hasil penelitian ini membuktikan teori model penerimaan teknologi (UTAUT) oleh Venkatesh et al. (2003) yang menyatakan salah satu penyebab perilaku pengguna sistem adalah effort expectancy. Prasetyo \& Anubhakti (2011) juga menemukan bahwa faktor yang mempengaruhi use behavior adalah effort expectancy. Begitu juga hasil penelitian oleh Sari (2011) dan Sari \& P.S. (2013) yang menunjukkan bahwa effort expectancy berpengaruh positif terhadap use behavior.

Effort expectancy dapat diartikan bahwa setiap individu akan meyakini dimana ada kemudahan dalam menggunakan sistem yang dapat menghemat tenaga dan waktu maka akan terdapat minat dalam melakukan pekerjaannya. Venkatesh et al. (2003) mendefinisikan effort expectancy sebagai tingkat kemudahan pengguna sistem yang akan dapat mengurangi upaya (tenaga dan waktu) individu dalam melakukan pekerjaannya. Melihat hasil penelitian menunjukkan bahwa peserta didik kelas XII SMK Negeri 2 Semarang memiliki effort expectancy dalam kriteria sedang. Artinya, beberapa peserta didik masih ada yang belum memahami bahwa effort expectancy akan memudahkan peserta didik untuk berperilaku dalam penggunaan suatu sistem. Hasil penelitian dapat disimpulkan bahwa semakin baik effort expectancy yang dimiliki oleh peserta didik maka akan semakin meningkat pula use behavior Edmodo oleh peserta didik kelas XII SMK Negeri 2 Semarang.

\section{Pembahasan Pengaruh Social Influence terhadap Use behavior}

Hipotesis ketiga yang diajukan dalam penelitian ini menguji pengaruh social influence terhadap use behavior Edmodo pada peserta didik kelas XII SMK Negeri 2 Semarang. Hipotesis tersebut mengasumsikan 
bahwa semakin baik social influence yang dimiliki oleh peserta didik maka use behavior Edmodo juga akan meningkat. Hasil uji t pada Tabel 3 menunjukkan bahwa variabel social influence memiliki nilai signifikansi $0,740>$ 0,05 yang berarti bahwa social influence tidak berpengaruh signifikan terhadap use behavior Edmodo pada peseta didik kelas XII SMK Negeri 2 Semarang.

Hasil penelitian menunjukkan bahwa peserta didik kelas XII SMK Negeri 2 Semarang tidak terpengaruh pada faktor social influence dalam memanfaatkan Edmodo. Faktor sosial kedepannya dapat membantu dan bermanfaat untuk dirinya dalam menggunakan Edmodo. Penelitian ini sesuai dengan hasil penelitian dari Agustina (2013) yang menunjukkan tidak ada pengaruh secara positif dan signifikan effort expectancy terhadap use behavior. Namun dalam penelitian lain menunjukkan bahwa social influence berpengaruh positif signifikan terhadap use behavior. Sementara itu, Sari \& P.S. (2013) berhasil membuktikan pengaruh signifikan social influence terhadap use behavior.

\section{Pembahasan Pengaruh Facilitating Conditions terhadap Use behavior}

Hipotesis keempat yang diajukan dalam penelitian ini menguji pengaruh facilitating conditions terhadap use behavior Edmodo pada peserta didik kelas XII SMK Negeri 2 Semarang. Hipotesis tersebut mengasumsikan bahwa semakin baik facilitating conditions yang dimiliki oleh peserta didik maka use behavior Edmodo juga akan meningkat. Hasil uji t pada Tabel 3 menunjukkan bahwa variabel facilitating conditions memiliki nilai signifikansi 0,002 < 0,05 dan koefisien regresi menunjukkan hasil positif. Hal ini berarti facilitating conditions berpengaruh positif dan signifikan terhadap use behavior Edmodo pada peseta didik kelas XII SMK Negeri 2 Semarang.

Hasil penelitian ini sesuai dengan teori model penerimaan teknologi (UTAUT) oleh Venkatesh et al. (2003) bahwa yang menyebabkan perilaku pengguna (use behavior) salah satunya adalah adanya facilitating conditions. Hasil penelitian ini sama dengan yang diperoleh Rivai (2014) dan Agustina (2013) dalam penelitiannya yang menunjukkan bahwa terdapat pengaruh positif dan signifikan facilitating conditions terhadap use behavior. Begitu juga menurut Sikumbang (2014) dan Haryanto (2017) dalam penelitiannya yang menunjukkan bahwa facilitating conditions berpengaruh positif dan signifikan terhadap use behavior.

Peserta didik kelas XII SMK Negeri 2 Semarang menunjukkan bahwa mereka memiliki facilitating conditions dalam kriteria tinggi yang kedepannya dapat membantu dan bermanfaat untuk dirinya. Menyadari adanya facilitating conditions akan memudahkan peserta didik untuk berperilaku dalam penggunaan suatu sistem.

\section{Pembahasan Pengaruh Behavioral intention terhadap Use behavior}

Hipotesis kelima yang diajukan dalam penelitian ini menguji pengaruh behavioral intention terhadap use behavior Edmodo pada peserta didik kelas XII SMK Negeri 2 Semarang. Hipotesis tersebut mengasumsikan bahwa semakin baik behavioral intention yang dimiliki oleh peserta didik maka use behavior Edmodo juga akan meningkat. Hasil uji $\mathrm{t}$ pada Tabel 3 menunjukkan bahwa variabel behavioral intention memiliki nilai signifikansi 0,002 $<0,05$ dan koefisien regresi menunjukkan hasil positif. Hal ini berarti bahwa behavioral intention berpengaruh signifikan dan positif terhadap use behavior Edmodo pada peseta didik kelas XII SMK Negeri 2 Semarang.

Hasil penelitian menunjukkan bahwa peserta didik kelas XII SMK Negeri 2 Semarang memiliki behavioral intention dalam kriteria tinggi. Behavioral intention merupakan keinginan seseoarang dalam menggunakan teknologi informasi dengan tujuan-tujuan yang diinginkannya. Venkatesh et al. (2003) mendefinisikan behavioral intention sebagai niat perilaku dapat didefinisikan sebagai ukuran kekuatan niat seseorang untuk melakukan perilaku tertentu. 
Hasil penelitian ini sesuai dengan teori model penerimaan teknologi (UTAUT) oleh Venkatesh et al. (2003) yang menyebabkan perilaku pengguna salah satunya adalah behavioral intention. Agustina (2013) menunjukkan hasil penelitian bahwa behavioral intention memiliki pengaruh terhadap use behavior. Begitu juga dengan Sarbani \& Astuti (2013) yang menemukan pengaruh positif dan signifikan behavioral intention terhadap use behavior.

\section{Pembahasan Pengaruh Performace Expectancy terhadap Behavioral intention} Hipotesis keenam yang diajukan dalam penelitian ini menguji pengaruh performance expectancy terhadap behavioral intention pada peserta didik kelas XII SMK Negeri 2 Semarang. Hipotesis tersebut mengasumsikan bahwa semakin baik performance expectancy yang dimiliki peserta didik maka behavioral intention yang dimiliki juga akan meningkat. Hasil uji t pada Tabel 3 menunjukkan bahwa variabel performance expectancy menunjukkan nilai signifikansi $0,000<0,05$ dan koefisien regresi positif. Hal ini berarti performance expectancy berpengaruh positif dan signifikan terhadap behavioral intention pada peserta didik kelas XII SMK Negeri 2 Semarang.

Penelitian yang dilakukan oleh Sikumbang (2014) menunjukkan bahwa terdapat pengaruh positif dan signifikan performance expectancy terhadap behavioral intention. Hasil yang sama juga diperoleh Destaningrum, Suprapto, \& Wardani (2018). Hal ini sesuai dengan pendapat Venkatesh et al. (2003) yang menjelaskan bahwa performance expectancy memiliki pengaruh terhadap niat keperilakuan dalam menggunakan suatu sistem. Seseorang yang memiliki performance expectancy akan mempengaruhi niat keperilakuan dalam menggunakan suatu sistem baru, berbeda dengan jika seseorang tersebut tidak memiliki performance expectancy. Peserta didik kelas XII SMK Negeri 2 Semarang menunjukkan bahwa mereka memiliki performance expectancy yang kedepannya dapat membantu dan bermanfaat untuk dirinya. Menyadari adanya performance expectancy akan meningkatkan niat perilaku peserta didik dalam penggunaan suatu sistem.

\section{Pembahasan Pengaruh Effort Expectancy terhadap Behavioral intention}

Hipotesis ketujuh yang diajukan dalam penelitian ini menguji pengaruh effort expectancy terhadap behavioral intention pada peserta didik kelas XII SMK Negeri 2 Semarang. Hipotesis tersebut mengasumsikan bahwa semakin baik effort expectancy yang dimiliki peserta didik maka behavioral intention yang dimiliki juga akan meningkat. Hasil uji t pada Tabel 3 menunjukkan bahwa variabel effort expectancy menunjukkan nilai signifikan 0,189>0,05 yang berarti bahwa effort expectancy tidak berpengaruh positif dan signifikan terhadap behavioral intention pada peserta didik kelas XII SMK Negeri 2 Semarang.

Hasil penelitian ini sesuai dengan hasil dari penelitian-penelitian sebelumnya seperti yang ditemukan oleh Mustaqim, Kusyanti, \& Aryadita (2018) dan Destaningrum et al. (2018) yang menunjukkan bahwa tidak adanya pengaruh yang signifikan diantara faktor effort expectancy terhadap behavioral intention. Hasil yang sama juga ditemukan oleh Sikumbang (2014) yang tidak berhasil menemukan pengaruh positif dan signifikan effort expectancy terhadap behavioral intention. Kurniabudi \& Assegaff (2016) juga membuktikan hasil yang sama bahwa tidak terdapat pengaruh positif dan signifikan effort expectancy terhadap behavioral intention.

\section{Pembahasan Pengaruh Social Influence terhadap Behavioral intention}

Hipotesis kedelapan yang diajukan dalam penelitian ini menguji pengaruh social influence terhadap behavioral intention pada peserta didik kelas XII SMK Negeri 2 Semarang. Hipotesis tersebut mengasumsikan bahwa semakin baik social influence yang dimiliki peserta didik maka behavioral intention yang dimiliki juga akan meningkat. 
Hasil uji t pada Tabel 3 menunjukkan bahwa variabel social influence menunjukkan nilai signifikan $0,150>0,05$ yang berarti bahwa social influence tidak berpengaruh positif dan signifikan terhadap behavioral intention pada peserta didik kelas XII SMK Negeri 2 Semarang.

Hasil penelitian ini tidak mampu membuktikan konsep dalam model UTAUT. Hasil penelitian ini sesuai dengan temuan peneliti-peneliti sebelumnya seperti Kurniabudi \& Assegaff (2016) yang menunjukkan social influence tidak berpengaruh signifikan terhadap behavioral intention. Hasil yang kurang lebih sama juga diperoleh Bendi \& Aliyanto (2014) yang menunjukkan bahwa social influence tidak berpengaruh terhadap behavioral intention. Sikumbang (2014) juga menunjukkan bahwa tidak terdapat pengaruh social influence terhadap behavioral intention. Berbeda dengan peneliti lainnya, Destaningrum et al. (2018) berhasil menemukan pengaruh positif dan signifikan social influence terhadap behavioral intention.

Peserta didik kelas XII SMK Negeri 2 Semarang menunjukkan bahwa mereka belum memiliki social influence yang signifikan untuk meningkatkan niat perilaku dalam penggunaan suatu sistem. Hasil penelitian menunjukkan bahwa semakin kecil social influence yang dimiliki oleh peserta didik maka akan semakin menurun pula niat perilaku (behavioral intention) untuk menggunakan Edmodo oleh peserta didik kelas XII SMK Negeri 2 Semarang.

\section{Pembahasan Pengaruh Facilitating Conditions terhadap Behavioral intention}

Hipotesis kesembilan yang diajukan dalam penelitian ini menguji pengaruh facilitating conditions terhadap behavioral intention pada peserta didik kelas XII SMK Negeri 2 Semarang. Hipotesis tersebut mengasumsikan bahwa semakin baik facilitating conditions yang dirasakan peserta didik maka behavioral intention yang dimiliki juga akan meningkat. Hasil uji t pada Tabel 3 menunjukkan bahwa variabel facilitating conditions menunjukkan nilai signifikan 0,000 $<0,05$ dengan koefisien regresi positif. Hal ini berarti bahwa facilitating conditions berpengaruh positif dan signifikan terhadap behavioral intention pada peserta didik kelas XII SMK Negeri 2 Semarang.

Hasil penelitian ini sesuai dengan pendapat Venkatesh et al. (2003) bahwa facilitating conditions memiliki pengaruh terhadap niat keperilakuan dalam menggunakan suatu sistem. Begitu juga hasil penelitian Kurniabudi \& Assegaff (2016) yang menunjukkan bahwa terdapat pengaruh positif facilitating conditions terhadap behavioral intention. Seseorang yang merasa bahwa dirinya sangat terfasilitasi oleh lingkungan sekitar akan mempengaruhi niat keperilakuannya dalam menggunakan suatu sistem baru di dalam lingkungan tersebut, berbeda dengan jika seseorang tersebut tidak merasa terbantu dengan fasilitas yang ada. Penelitian ini juga sejalan dengan penelitian sebelumnya, dimana peserta didik kelas XII SMK Negeri 2 Semarang menunjukkan bahwa mereka merasa terfasilitasi oleh lingkungan yang kedepannya dapat membantu dan bermanfaat untuk dirinya. Menyadari adanya fasilitas yang sangat membantu akan meningkatkan niat perilaku peserta didik dalam penggunaan suatu sistem.

Pembahasan Pengaruh Performace expectancy terhadap Use behavior melalui Behavioral intention

Hasil penelitian menunjukkan bahwa performance expectancy berpengaruh signifikan terhadap use behavior melalui behavioral intention pada peserta didik kelas XII SMK N 2 Semarang. Hal ini didasarkan pada hasil uji sobel melalui aplikasi Sobel Test yaitu diperoleh nilai sobel test statistic sebesar 3,16299>1,65346 dengan nilai signifikansi One-tailed probability 0,000 < 0,05 . Hal ini berarti bahwa secara tidak langsung performance expectancy berpengaruh terhadap use behavior melalui behavioral intention. Besarnya pengaruh langsung performance expectancy adalah adalah 0,171 atau $17,1 \%$ sedangkan besarnya 
pengaruh tidak langsung adalah 0,099 atau 9,9\% sehingga total pengaruh adalah sebesar 0,270 atau $27 \%$.

Hasil penelitian ini selaras dengan model teori UTAUT menurut Venkatesh et al. (2003) yang mengemukakan bahwa performance expectancy dapat mempengaruhi use behavior melalui behavioral intention. Kurniabudi \& Assegaff (2016) berhasil membuktikan adanya pengaruh signifikan performance expectancy terhadap use behavior melalui behavioral intention. Begitu juga dengan hasil penelitian Sedana \& Wijaya (2009) yang menunjukkan bahwa performance expectancy mempengaruhi use behavior melalui adanya variabel mediasi yaitu behavioral intention.

Hasil tersebut dapat diketahui bahwa pengaruh tidak langsung lebih kecil dari hasil pengaruh langsung namun tetap signifikan. Lebih rendahnya pengaruh tidak langsung menunjukkan bentuk partial mediation yang berarti bahwa dalam penelitian ini variabel mediasi yaitu behavioral intention tidak mampu memediasi secara sempurna pengaruh performance expectancy terhadap use behavior dalam menggunakan Edmodo. Performance expectancy sudah dianggap penting dan berpengaruh terhadap use behavior dalam menggunakan Edmodo pada peserta didik kelas XII SMK Negeri 2 Semarang. Performance expectancy yang tinggi mengenai segala hal yang berkaitan dengan use behavior, tentu akan meningkatkan atau membentuk perilaku pengguna dalam menggunakan Edmodo tanpa harus memperhatikan behavioral intention.

\section{Pembahasan Pengaruh Effort expectancy terhadap Use Behavor melalui Behavioral intention}

Hasil penelitian menunjukkan bahwa tidak terdapat pengaruh signifikan effort expectancy terhadap use behavior melalui behavioral intention pada peserta didik kelas XII SMK Negeri 2 Semarang. Hasill ini berdasarkan hasil uji sobel melalui aplikasi Sobel Test yaitu diperoleh nilai sobel test statistic sebesar $-1,90377<1,65346$ dengan nilai signifikansi One-tailed probability 0,028 $<0,05$. Hal ini berarti bahwa secara tidak langsung performance expectancy tidak berpengaruh terhadap use behavior melalui behavioral intention. Besarnya pengaruh langsung performance expectancy adalah adalah 0,169 atau $16,9 \%$ sedangkan besarnya pengaruh tidak langsung adalah -0,023 atau $2,3 \%$ sehingga total pengaruh adalah sebesar 0,146 atau $14,6 \%$.

Hasil tersebut dapat diketahui bahwa pengaruh tidak langsung lebih kecil dari hasil pengaruh langsung namun tetap signifikan tetapi melebihi batas yang ditentukan. Lebih rendahnya pengaruh tidak langsung menunjukkan bentuk partial mediation yang berarti bahwa dalam penelitian ini variabel mediasi yaitu behavioral intention tidak mampu memediasi secara sempurna pengaruh effort expectancy terhadap use behavior dalam menggunakan Edmodo. Effort expectancy masih dianggap rendah sehingga tidak berpengaruh terhadap use behavior dalam menggunakan Edmodo melalui behavioral intention pada peserta didik kelas XII SMK Negeri 2 Semarang.

Penelitian ini menyatakan tidak terdapat pengaruh signifikan effort expectancy terhadap use behavior melalui behavioral intention. Hasil penelitian ini tidak selaras dengan model teori UTAUT. Namun demikian, hasil penelitian ini sejalan dengan hasil yang diperoleh Setiawan (2017) yang mengemukakan bahwa effort expectancy tidak dapat mempengaruhi use behavior melalui behavioral intention. Hasil yang sama juga ditemukan Mustaqim et al. (2018), Mentaya, Sunarto, \& Wulandari (2015) dan Kurniabudi \& Assegaff (2016) dalam penelitian mereka yang menunjukkan bahwa tidak terdapat pengaruh positif effort expectancy terhadap use behavior melalui behavioral intention.

\section{Pembahasan Pengaruh Social Influence terhadap Use behavior melalui Behavioral intention}

Hasil penelitian menunjukkan bahwa social influence berpengaruh positif dan signifikan terhadap use behavior melalui 
behavioral intention pada peserta didik kelas XII SMK N 2 Semarang. Hal ini dadasrkan pada hasil uji sobel melalui aplikasi Sobel Test yaitu diperoleh nilai sobel test statistic sebesar $1,98011>1,65346$ dengan nilai signifikansi One-tailed probability $0,023<0,05$. Hal ini berarti bahwa secara tidak langsung social influence berpengaruh terhadap use behavior melalui behavioral intention.

Besarnya pengaruh langsung social influence adalah adalah $-0,023$ atau $-2,3 \%$ sedangkan besarnya pengaruh tidak langsung adalah 0,023 atau 2,3\% sehingga total pengaruh adalah sebesar 0 atau $0 \%$. Hasil tersebut dapat diketahui bahwa pengaruh tidak langsung lebih besar dari hasil pengaruh langsung. Lebih rendahnya pengaruh langsung menunjukkan bentuk full mediation yang berarti bahwa dalam penelitian ini variabel mediasi yaitu behavioral intention mampu memediasi secara sempurna pengaruh social influence terhadap use behavior dalam menggunakan Edmodo.

Hasil penelitian ini selaras dengan model teori UTAUT menurut Venkatesh et al. (2003) yang mengemukakan bahwa social influence dapat mempengaruhi use behavior melalui behavioral intention. Agustina (2013) berhasil menunjukkan bahwa adanya pengaruh positif social influence terhadap use behavior melalui behavioral intention. Begitu juga dengan hasil penelitian dari Rivai (2014) dan Mustaqim et al. (2018) yang menemukan bahwa social influence mempengaruhi use behavior melalui adanya variabel mediasi yaitu behavioral intention.

\section{Pembahasan Pengaruh Facilitating Conditions terhadap Use behavior melalui Behavioral intention}

Hasil penelitian ini menunjukkan bahwa facilitating conditions berpengaruh positif dan signifikan terhadap use behavior melalui behavioral intention pada peserta didik kelas XII SMK N 2 Semarang. Hal ini berdasarkan pada hasil uji sobel melalui aplikasi Sobel Test yaitu diperoleh nilai sobel test statistic sebesar 2,80108>1,65346 dengan nilai signifikansi One-tailed probability $0,002<0,05$. Hal ini berarti bahwa secara tidak langsung facilitating conditions berpengaruh terhadap use behavior melalui behavioral intention.

Besarnya pengaruh langsung facilitating conditions adalah 0,237 atau $23,7 \%$ sedangkan besarnya pengaruh tidak langsung adalah 0,067 atau $6,7 \%$ sehingga total pengaruh adalah sebesar 0,304 atau $30,4 \%$. Hasil tersebut dapat diketahui bahwa pengaruh tidak langsung lebih kecil dari hasil pengaruh langsung namun tetap signifikan. Lebih rendahnya pengaruh tidak langsung menunjukkan bentuk partial mediation yang berarti bahwa dalam penelitian ini variabel mediasi yaitu behavioral intention tidak mampu memediasi secara sempurna pengaruh facilitating conditions terhadap use behavior dalam menggunakan Edmodo. Facilitating conditions sudah dianggap penting dan berpengaruh terhadap use behavior dalam menggunakan Edmodo pada peserta didik kelas XII SMK Negeri 2 Semarang.

Hasil penelitian ini selaras dengan model teori UTAUT menurut Venkatesh et al. (2003) yang mengemukakan bahwa facilitating conditions dapat mempengaruhi use behavior melalui behavioral intention. Hasil penelitian ini mendukung temuan dari Bendi \& Aliyanto (2014) dan menurut Kurniabudi \& Assegaff (2016) yang menemukakan bahwa facilitating conditions mempengaruhi use behavior melalui adanya variabel mediasi yaitu behavioral intention. Facilitating conditions yang tinggi mengenai segala hal yang berkaitan dengan use behavior, tentu akan meningkatkan atau membentuk perilaku pengguna (use behavior) dalam menggunakan Edmodo tanpa harus memperhatikan behavioral intention.

\section{SIMPULAN}

Model UTAUT merupakan model penerimaan teknologi informasi yang dikembangkan oleh Venkatesh et al. (2003). Penelitian ini telah membuktikan model UTAUT untuk menganalisis determinan pemanfaatan Edmodo pada SMK Negeri 2 Semarang. Hasilnya menunjukkan bahwa 
konstruk performance expectancy, effort expectancy, dan facilitating conditions terbukti berpengaruh positif dan signifikan terhadap behavioral intention. Sementara konstruk social influence tidak terbukti berpengaruh signifikan. Hasil berikutnya menunjukkan bahwa hanya konstruk performance expectancy dan facilitating conditions yang terbukti berpengaruh positif dan signifikan terhadap use behavior. Sementara konstruk social influence dan effort expectancy tidak terbukti mempunyai pengaruh signifikan. Artinya, pemanfaatan Edmodo oleh siswa hanya dipengaruhi persepsi kebermanfaatan dan ketersediaan fasilitas (internet). Konstruk behavioral intention terbukti berpengaruh positif dan signifikan terhadap use behavior.

Hasil pengujian pengaruh tidak langsung keempat konstruk terhadap use behavior melalui behavioral intention menunjukkan hasil yang mendukung model UTAUT walaupun belum sepenuhnya berhasil. Hasilnya menunjukkan tidak ada pengaruh signifikan effort expectancy terhadap use behavior melalui behavioral intention.

\section{DAFTAR PUSTAKA}

Agustina, P. (2013). Pengaruh Faktor UTAUT terhadap E-retention dengan E-satisfaction sebagai Variabel Antara (Studi pada E-learning karyawan PT Indo Tambangaraya Megah Tbk Jakarta Office). Universitas Indonesia.

Asrori, \& Fachrurrozie. (2011). Penggunaan E-learning ILMO untuk Meningkatkan Mutu Perkuliahan di Fakultas Ekonomi. Dinamika Pendidikan, VI(1), 1-14.

Bendi, R. K. J., \& Aliyanto, A. (2014). Analisis Pengaruh Perbedaan Gender pada Model UTAUT. In Seminar Nasional Teknologi Informasi dan Komunikasi Terapan 2014 (SEMANTIK 2014) (Vol. 2014, pp.

\section{8-234). Semarang: Udinus.}

Chang, A. (2012). UTAUT and UTAUT 2: a Review and Agenda for Future Research. Journal The WINNERS, 13(9), 106-114.

Destaningrum, D., Suprapto, \& Wardani, N. H. (2018). Analisis Faktor Penerimaan Pengguna E-Learning SMA Negeri di Kota Blitar Menggunakan Model Unified Theory of Acceptance and Use of Technology ( UTAUT ). Jurnal Pengembangan Teknologi Informasi Dan Ilmu Komputer, 2(2), 723-732.

Dharmawati. (2017). Penggunaan Media eLearning Berbasis Edmodo Dalam Pembelajaran English for Business. QUERY: Jurnal Sistem Informasi, 01(01), 43-49.

Divayana, D. G. H. (2017). Evaluasi Pemanfaatan E-learning Menggunakan Model CSE-UUCLA. Cakrawala Pendidikan, XXXVI(2), 280-289.

Hartati, E. (2017). Analisis Sistem Penerapan E-Learning dengan Menggunakan Metode UTAUT (Unified Theory of Acceptanced Use of Technology) (Study Kasus: STMIK XYZ). Jurnal Ilmiah Informatika Global, 8(1), 13-18.

Haryanto. (2017). Kajian Implementasi Pembelajaran Berbasis E-learning dengan Pendekatan Unified Theory of Acceptance and Use of Technology (UTAUT) (Studi Kasus pada SMP AlAmanah Kota Tangerang Selatan). Jurnal Khatulistiwa Informatika, V(1), 14-20.

Herayanti, L., Fuadunnazmi, M., \& Habibi. (2017). Pengembangan media pembelajaran berbasis MOODLE pada mata kuliah Fisika Dasar. Cakrawala Pendidikan, XXXVI(2), 210-219. 
Kurniabudi, K., \& Assegaff, S. (2016). Analisis perilaku penerimaan edmodo pada perkuliahan dengan model UTAUT. TEKNOSI, 02(03), 1-10.

Mckeown, T., \& Anderson, M. (2016). UTAUT: capturing differences in undergraduate versus postgraduate learning? Education + Training, 58(9), 945-965. https://doi.org/10.1108/ET-07-20150058

Mentaya, A., Sunarto, M. J. D., \& Wulandari, S. H. E. (2015). FaktorFaktor Yang Berpengaruh Terhadap Penerimaan Aplikasi Brilian dengan Model UTAUT. JSIKA, 4(2), 1-10.

Muhsin, Thomas, P., \& Nurkhin, A. (2016). Intention to use E-Journal ; A Unified Theory of Acceptance and use of Technology Perspective. IOSR Journal of Research \& Method in Education (IOSR-JRME), 6(4), 100-106. https://doi.org/10.9790/7388060404100106

Mumpuni, A., \& Nurpratiwiningsih, L. (2018). Pengembangan pembelajaran berbasis web untuk meningkatkan kemampuan menulis kreatif mahasiswa PGSD. Cakrawala Pendidikan, XXXVII(2), 321-332.

Munir. (2010). Penggunaan Learning Management System (LMS) di Perguruan Tinggi: Studi Kasus di Universitas Pendidikan Indonesia. Cakrawala Pendidikan, XXIX(1), 109119.

Mustaqim, R. N., Kusyanti, A., \& Aryadita, H. (2018). Analisis Faktor-Faktor yang Memengaruhi Niat Penggunaan ECommerce XYZ Menggunakan Model UTAUT (Unified Theory Acceptance and Use Of Technology). Jurnal
Pengembangan Teknologi Informasi Dan Ilmu Komputer, 2(7), 2584-2593.

Prasetyo, B. H., \& Anubhakti, D. (2011). Kajian Penerimaan Sistem E-learning dengan Menggunakan Pendekatan UTAUT Studi Kasus Fakultas Teknologi Informasi Universitas Budi Luhur. BIT, 8(2), 45-47.

Rivai, M. B. (2014). Penerapan model the unified theory of acceptance and use of technology (UTAUT) untuk memahami tingkat penerimaan dan penggunaan e-learning (be smart) di Fakultas Teknik Universitas Negeri Yogyakarta. Universitas Negeri Yogyakarta.

Sancaka, M., \& Subagio, H. (2014). Analisa Faktor yang Mempengaruhi Penerimaan dan Penggunaan Kompas Epaper oleh Konsumen Harian KOMPAS di Jawa Timur dengan Menggunakan Kerangka Unified Theory of Acceptance and Use of Technology (UTAUT). Jurnal Manajemen Pemasaran Petra, 2(2), 112.

Sarbani, Y. A., \& Astuti, E. S. (2013). Analisis Penggunaan Teknologi Informasi pada Tenaga Kependidikan Sekolah (Studi Pada Tenaga Kependidikan Di Sekolah Milik Perkumpulan Dharmaputri Melalui Model UTAUT). Jurnal Profit, 7(1), 168-181.

Sari, F. (2011). Implementasi E-learning System dengan menggunakan model Unified Theory of Acceptance and Use of Technology (Studi Kasus: elearning Universitas Bina Darma). Jurnal Imiah MATRIK, 13(1), 1-13.

Sari, F., \& P.S., S. D. (2013). Intensitas Perilaku Pengguna E-learning System dengan Model UTAUT. Jurnal Imiah 
MATRIK, 15(3), 209-220.

Sedana, I. G. N., \& Wijaya, S. W. (2009). Penerapan Model UTAUT untuk Memahami Penerimaan dan Penggunaan Learning Management System Studi Kasus: Experential Elearning of Sanata Dharma University. Jurnal Sistem Informasi, 5(2), 114120.

Setiawan, A. (2017). Pengaruh Penerapan Remote Electronic Voting System (REVS) Terhadap Tingkat Partisipasi Pemilih Menggunakan Model UTAUT. Jurnal Teknologi Terapan, 3(1), 1-6.

Sikumbang, E. D. (2014). Penerapan Model UTAUT dalam Sistem Pembelajaran E-learning. Jurnal Paradigma, XVI(1), 85-92.

Tan, P. J. B. (2013). Applying the UTAUT to Understand Factors Affecting the Use of English E-Learning Websites in Taiwan. SAGE Open, 3(4), 1-12. https://doi.org/10.1177/215824401350 3837

Tarhini, A., El-Masri, M., Ali, M., \& Serrano, A. (2016). Extending the UTAUT model to understand the customers' acceptance and use of internet banking in Lebanon: A structural equation modeling approach.
Information Technology \& People, 29(4), 830-849. https://doi.org/10.1108/ITP-02-20140034

Tarhini, A., Masa'deh, R., Al-Busaidi, K. A., Mohammed, A. B., \& Maqableh, M. (2017). Factors influencing students' adoption of e-learning: a structural equation modeling approach. Journal of International Education in Business, 10(2), 164-182. https://doi.org/10.1108/JIEB-09-20160032

Thomas, P., \& Setiaji, K. (2014). Elearning dengan pendekatan kooperatif tipe jigsaw untuk meningkatkan aktivitas dan hasil belajar mahasiswa. Dinamika Pendidikan, IX(1), 21-40.

Venkatesh, V. (2012). Consumer Acceptance and Use of Information Technology: Extending the Unified Theory of Acceptance and Use of Technology. MIS Quarterly, 36(1), 157-178.

Venkatesh, V., Morris, M. G., Davis, G. B., \& Davis, F. D. (2003). User acceptance of information technology: Toward a unified view. MIS Quarterly, 27(3), 425-478. https://doi.org/10.2307/30036540 